ALI.2.2003.205

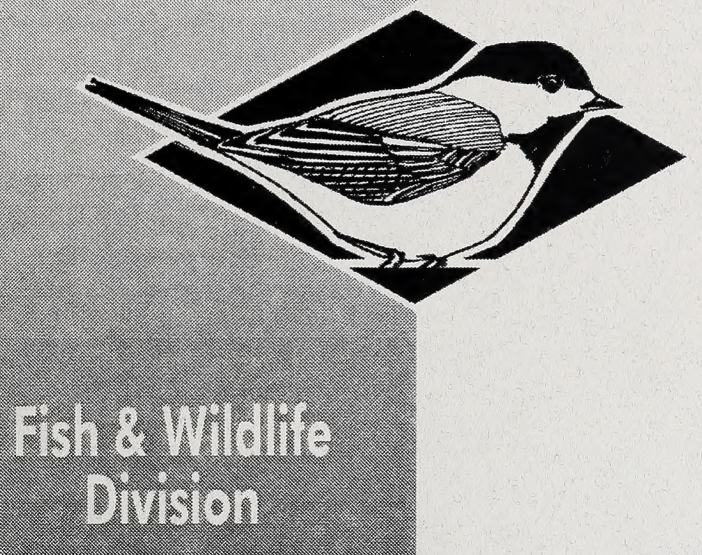

\title{
Distribution and Habitat Associations of the Long-toed Salamander (Ambystoma macrodactylum) in the Oldman River Drainage
}

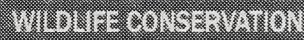
HWD :3010

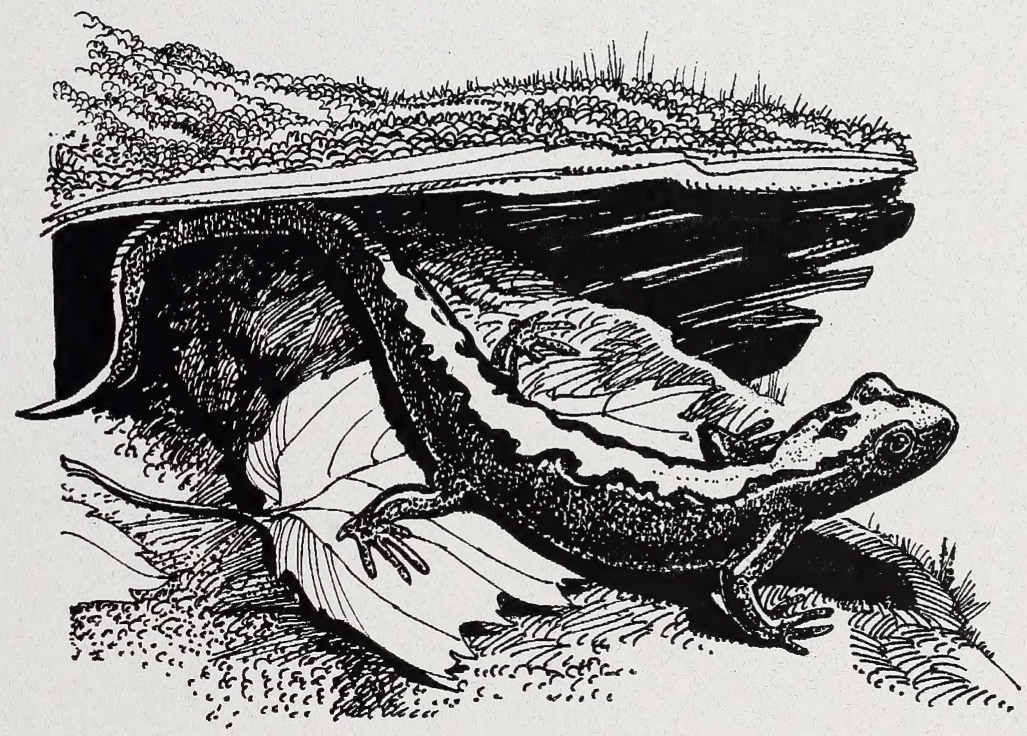


Digitized by the Internet Archive in 2016 


\title{
Distribution and Habitat Associations of the Long-toed Salamander (Ambystoma macrodactylum) in the Oldman River Drainage
}

\author{
Kim Pearson
}

Alberta Species at Risk Report No. 75

March 2003

40

SUSTAINABLE RESOURCE DEVELOPMENT

Fish \& Wildlife

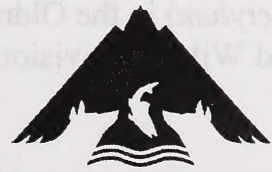

Alberta Conservation Association 
Publication No. 75

ISBN: 0-7785-2912-6 (Printed Edition)

ISBN: 0-7785-2913-4 (On-line Edition)

ISSN: 1496-7219 (Printed Edition)

ISSN: 1496-7146 (On-line Edition)

Illustration by: Brian Huffman

For copies of this report, contact:

Information Centre- Publications

Alberta Environment/ Alberta Sustainable Resource Development

Main Floor, Great West Life Building

9920-108 Street

Edmonton, Alberta, Canada T5K 2M4

Telephone: (780) 422-2079

OR

Information Service

Alberta Environment/ Alberta Sustainable Resource Development \#100, 3115- 12 Street NE

Calgary, Alberta, Canada T2E 7J2

Telephone: (403) 297- 3362

OR

Visit our web site at:

http://ww3.gov.ab.ca/srd/fw/riskspecies/

This publication can be cited as:

Pearson, K. 2003. Distribution and Habitat Associations of the Long-toed Salamander

(Ambystoma macrodactylum) in the Oldman River Drainage. Alberta Sustainable Resource Development, Fish and Wildlife Division, Alberta Species at Risk Report No. 75, Edmonton, AB. 25 pp. 


\section{TABLE OF CONTENTS}

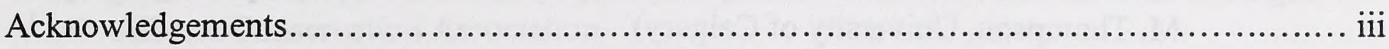

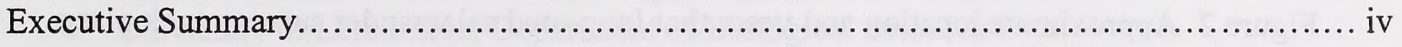

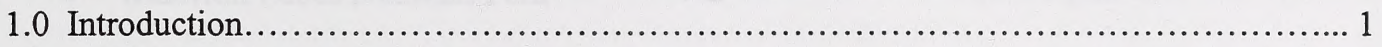

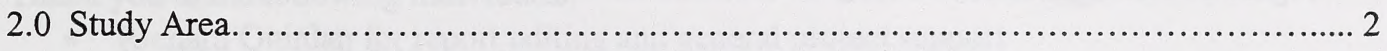

3.0 Methods........................................................................ 4

4.0 Results...................................................................... 7

5.0 Discussion and Recommendations.............................................. 11

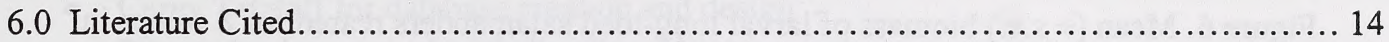

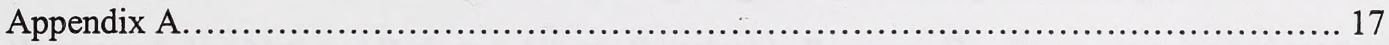




\section{LIST OF FIGURES}

Figure 1. Known distribution of $A$. macrodactylum in North America (map designed by $\mathrm{M}$. Thompson, University of Calgary) .....................................

Figure 2. Approximate location and years that long-toed salamander surveys took place

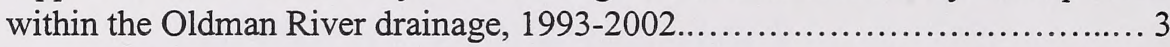

Figure 3. The distribution of long-toed salamanders in southwest Alberta, 1993-2002 ... 7

Figure 4. The relative distribution of long-toed salamanders and fish species (trout and/or minnows) in the Waterton and Castle River drainages, 2002 ........... 8

Figure 5. Mean ( \pm s.e.) proportion survival of larval long-toed salamanders reared for 8 weeks in experimental ponds containing dragonfly larvae, minnows, and trout

Figure 6. Mean ( \pm s.e.) biomass of larval long-toed salamanders reared for 8 weeks in experimental ponds containing dragonfly larvae, minnows, and trout..........10

\section{LIST OF TABLES}

Table 1. Long-toed salamander surveys within the Oldman River drainage, 1993-2002

Table 2. Number of sites where long-toed salamanders, trout and minnows were observed in the Waterton and Castle River drainages, 2001-2002. 


\section{ACKNOWLEDGEMENTS}

Funding and in-kind support for this project were provided by the following:

- Alberta Conservation Association

- Alberta Sustainable Resource Development, Fish and Wildlife Division

- University of Lethbridge, Department of Biological Sciences

- Waterton Lakes National Park

Thank you to the following individuals:

- Richard Quinlan for report editing and general project support

- Dr. Cam Goater for project management and support

- Sarah Pearson, Michael Taylor, Mary Coleman and Robbie Bowness for assisting with field work

- Lisa Wilkinson, Rob Watt, Daryl Wig, Terry Clayton and Lorne Fitch for providing information and support

- Brad Downey for preparing GIS figures

- Carey Tetzlaff for database creation and design

- Private landowners who kindly allowed access to their properties

Waterton Lakes National Park and Alberta Sustainable Resource Development provided research and collection permits. The research was conducted following University of Lethbridge Animal Welfare Committee animal care protocol (\#206). 


\section{EXECUTIVE SUMMARY}

Long-toed salamanders are designated as Sensitive in Alberta due to their occurrence in patchy, isolated populations, and their vulnerability to habitat destruction or alteration. Three long-toed salamander breeding populations have been identified within the Oldman River drainage: Waterton Lakes National Park, Castle River and Crowsnest. Seven independent long-toed salamander presence/absence surveys occurred in those areas between 1993 and 2002.

Numerous field and experimental studies in Western North America have documented long-toed salamander population declines or extirpations due to the presence of non-native trout. In Alberta, stocking of non-native trout into mountain lakes has been a common practice since the early 1900 's. Anecdotal evidence indicates that long-toed salamanders and fish rarely co-exist in southwest Alberta waterbodies.

The objectives of this study were: 1) to increase knowledge of the distribution of long-toed salamanders in southwest Alberta, 2) to merge data derived from seven independent amphibian surveys in southwest Alberta, and 3) to characterize habitat/occurrence associations for long-toed salamanders in southwest Alberta, focusing on their distribution relative to introduced fishes. Results of a simulated pond experiment that examined the effects of various predators on longtoed salamanders are also presented.

Forty-two lakes and ponds were examined for presence/no detection of long-toed salamanders and fish in 2002. Occurrence data collected during other surveys were derived from related reports. Long-toed salamanders were detected at 68 of 135 sites surveyed 1993-2002, at elevations from $1275 \mathrm{~m}$ to $2018 \mathrm{~m}$. Thirteen previously unrecorded long-toed salamander breeding locations were documented in 2002. As has been observed in Montana, Idaho and Washington State, trout and long-toed salamanders do not co-exist in wetlands in the Castle and Waterton River drainages. Of the 31 wetlands where long-toed salamanders were observed, $100 \%$ lacked trout and $94 \%$ lacked minnows.

Experimental ponds are commonly used to evaluate variation in amphibian life histories due to predation and competition. The effects of three predators (rainbow trout fry, fathead minnows, and dragonfly larvae) on the survival and growth rate of larval long-toed salamanders were evaluated in a series of $1200 \mathrm{~L}$ plastic tanks at the University of Lethbridge. On average, fewer than $10 \%$ of larval salamanders survived 30 days in the trout and minnow ponds, whereas between $25-60 \%$ of the larvae in control and dragonfly ponds survived. Exposure to minnows reduced the mass of larvae by $34-50 \%$ compared to larvae from the other three environments.

Results of this ongoing project provide improved understanding of long-toed salamander habitat requirements in southwest Alberta, specifically the effects of non-native fishes on long-toed salamanders. Recommendations include continued long-toed salamander surveys, environmental monitoring, aquatic habitat restoration, and effective management of non-native species. 


\subsection{INTRODUCTION}

Throughout their range (Figure 1), long-toed salamanders (Ambystoma macrodactylum) are known to inhabit a variety of terrestrial habitat types in proximity to suitable aquatic breeding habitats (Graham and Powell, 1999). Eight long-toed salamander breeding areas have been identified within Alberta, including three within the Oldman River drainage: Waterton Lakes National Park, Castle River and Crowsnest (Powell et. al., 1997). Seven independent long-toed salamander surveys occurred in those areas between 1993 and 2002.

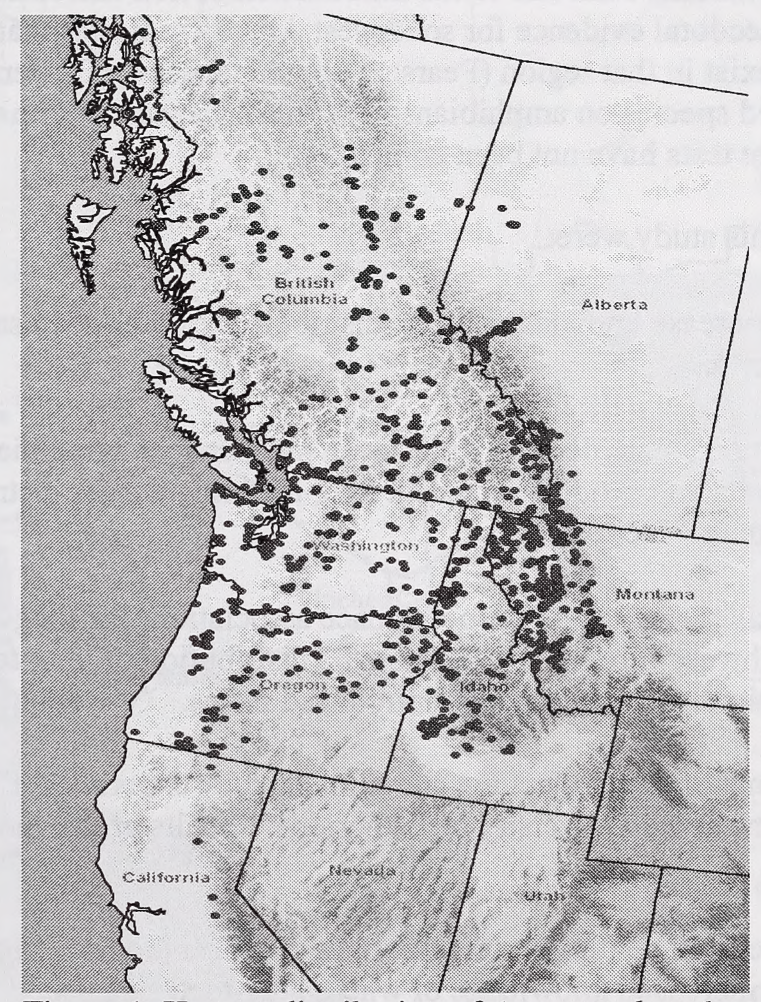

Figure 1. Known distribution of A. macrodactylum in North America (map designed by M. Thompson, University of Calgary).

Long-toed salamanders are designated as Sensitive in Alberta due to their occurrence in patchy, isolated populations, and their vulnerability to habitat destruction or alteration (ASRD, 2000). The species is typically the top vertebrate predator in fishless lakes and ponds throughout its range.

One of the foremost current threats to global amphibian diversity is the presence of non-native species in amphibian breeding habitats (Alford and Richards, 1999). Numerous field studies in Western North America have identified amphibian populations, those of long-toed salamanders in particular, that have experienced declines or extirpations due to the introduction of non-native trout (Bradford, 1989; Bradford and Graber, 1993; Tyler et. al., 1998; Funk and Dunlap, 1999; 
Matthews et. al., 2001; Pilliod and Peterson, 2001). Several experimental investigations have also described negative effects of introduced fishes on various amphibian species (Tyler et. al., 1998b; Figiel, Jr. and Semlitsch, 1990). Further, preference studies show that reproductive amphibians avoid calling and ovipositing in waterbodies containing fish predators (Kats and Sih, 1992; Resetarits Jr. and Wilbur, 1991).

In Alberta, stocking of non-native trout into mountain lakes has been a common practice since the early 1900's (Donald, 1987). At least one documented long-toed salamander extirpation has occurred in Banff National Park due to the introduction of non-native trout (Holroyd and Van Tighem, 1983). Anecdotal evidence for southwest Alberta indicates that long-toed salamanders and fish rarely co-exist in that region (Pearson, unpubl. observ.). Evidence for the negative effects of introduced species on amphibians in Western Canada is primarily anecdotal and to date, the appropriate tests have not been completed.

The objectives of this study were:

- To increase knowledge of the distribution of long-toed salamanders in southwest Alberta.

- To merge data derived from seven independent amphibian surveys in southwest Alberta and produce a current long-toed salamander distribution map for the Oldman River drainage.

- To characterize habitat/occurrence associations for long-toed salamanders in southwest Alberta, focusing on the distribution of long-toed salamanders in relation to the presence of introduced fishes.

The field components of this project are complimented by experimental work conducted under controlled conditions at the University of Lethbridge. Results of that work are described briefly in this document.

This ongoing project will result in a summary of the distribution of long-toed salamanders in southwest Alberta, increased knowledge of where long-toed salamanders do and do not exist in the region, and provide enhanced scientific understanding of the species' habitat requirements. Finally, our understanding of the effects of non-native fishes on long-toed salamanders in southern Alberta will be improved.

\subsection{STUDY AREA}

The 2002 study area was defined on the west by the Alberta/British Columbia border, on the south by the Canada/U.S.A. border, on the east by Highway 6, and on the north by Highway 3 . Surveys were completed at aquatic habitats (lakes and ponds) located within Waterton Lakes National Park (WLNP), the Bow-Crow Forest Reserve, and on privately owned properties. This area and portions of it were included in previous surveys described by Fukumoto (1995), Oseen et. al. (1995), Nelson et. al. (1995), Wallis et. al. (2002), Paton (2002) and Pearson (2001). Figure 2 outlines the approximate areas included in each survey. 


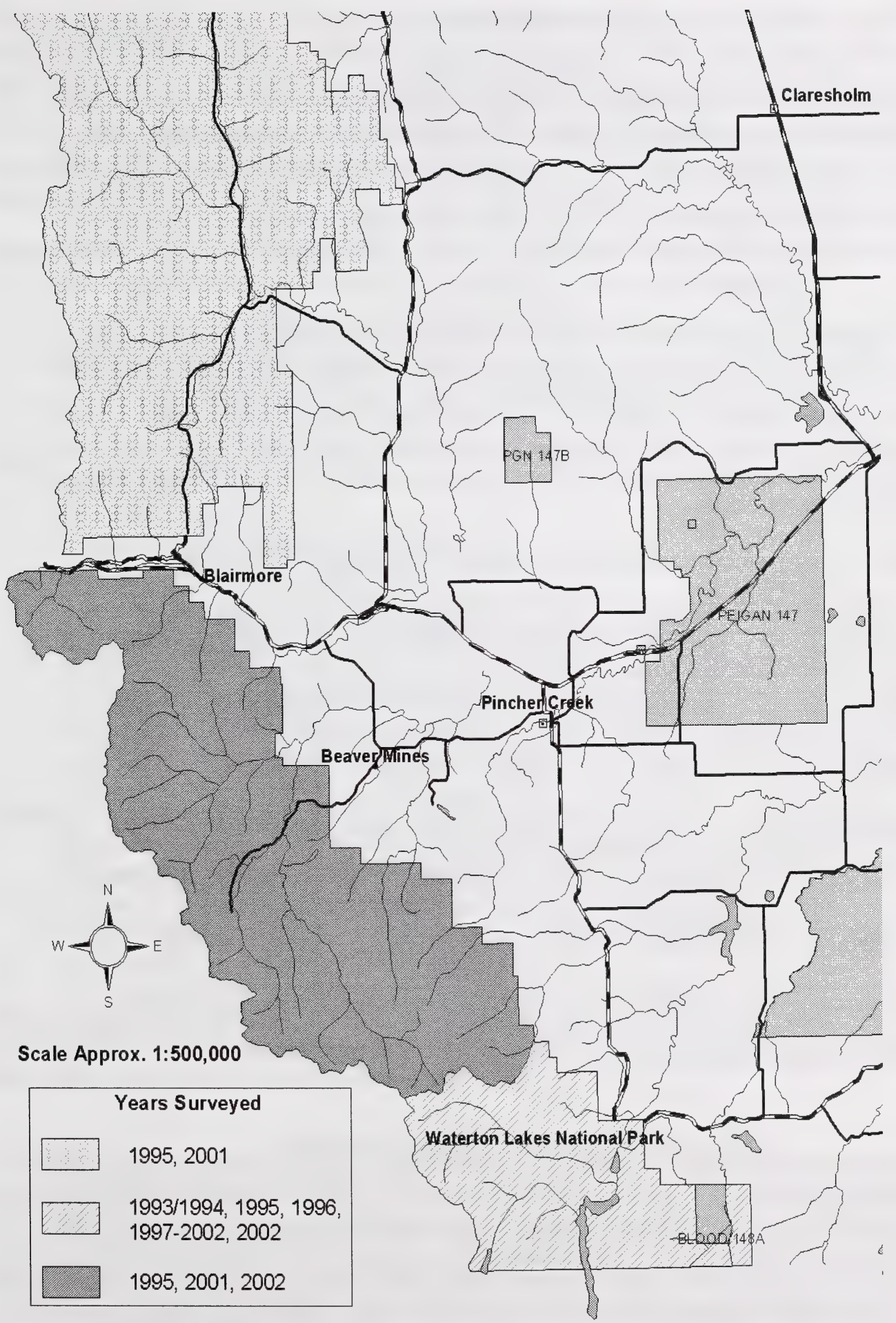

Figure 2. Approximate area and years that long-toed salamander surveys took place within the headwaters of the Oldman River drainage, 1993-2002. 


\subsection{METHODS}

\subsection{Distribution Data}

Thirty-nine previously unsurveyed lakes and ponds were examined for presence/no detection of long-toed salamanders May through September, 2002. Efforts were concentrated in areas not previously surveyed. Presence/no detection of long-toed salamanders at each site was determined through daytime shoreline surveys for eggs and larvae, as described by Thoms et. al. (1997). Surveys included the entire perimeter of each site. These survey methods parallel those used in ongoing and past long-toed salamander monitoring programs in the region (Paton, 2002; Pearson, 2001).

Long-toed salamander, western toad (Bufo boreas), Columbia spotted frog (Rana luteiventris), striped chorus frog (Pseudacris triseriata) and tiger salamander (Ambystoma tigrinum) occurrence data collected during all seven recorded surveys within the Oldman River drainage were derived from a series of related reports and entered into a database. Long-toed salamander distribution data were amalgamated and mapped using a Geographic Information System (ArcView). Table 1 lists general survey locations and dates. Figure 2 shows the approximate area covered by each survey that has taken place in the region.

Table 1. Long-toed salamander surveys within the Oldman River drainage, 1993-2002.

\begin{tabular}{|c|c|c|c|}
\hline Survey & Years & Locations & Reference \\
\hline Fukumoto & $1993-1994$ & WLNP & Fukumoto, 1995 \\
\hline Wallis et. al. & $1995-1996$ & WLNP & Wallis et. al., 2002 \\
\hline Oseen et. al. & $<1995$ & $\begin{array}{c}\text { WLNP, Castle River, } \\
\text { Crowsnest }\end{array}$ & Oseen et. al., 1995 \\
\hline Nelson et. al. & 1995 & $\begin{array}{c}\text { WLNP, Castle River, } \\
\text { Crowsnest }\end{array}$ & Nelson et. al., 1995 \\
\hline WLNP & $1997-2002$ & WLNP & Pearson, 2001 \\
\hline Paton & 2001 & $\begin{array}{c}\text { Castle River, } \\
\text { Crowsnest }\end{array}$ & $\begin{array}{c}\text { Paton, 2002 } \\
\text { Pearson }\end{array}$ \\
\hline
\end{tabular}

WLNP $=$ Waterton Lakes National Park

\subsection{Long-toed Salamander Habitat Associations}

Some reports on long-toed salamanders in Alberta have included anecdotal evidence of the species' habitat preferences (Fukumoto, 1995; Paton, 2002). Huynh et. al. (2002) reported that all surveyed long-toed salamander breeding wetlands in Athabasca and Kananaskis Valleys lacked fish. Paton (2001) recommended that the effects of fish on long-toed salamanders be researched in southwest Alberta. A goal of this study is to evaluate whether previously-identified and additional habitat preferences of the long-toed salamander in southwest Alberta can be confirmed through statistical investigation. 
Forty-two study sites located in the Waterton and Castle River drainages were visited between 30 May and 15 September, 2002. A suite of 17 aquatic and riparian habitat characteristics (listed and briefly described below) were measured at randomly-chosen points on the north, south, east and west shores of each study site (four replicates per site). All characteristics were measured at 27 of the sites visited in 2002. A limited number of characteristics $\left(^{*}\right)$ were measured at the other 15 sites surveyed in 2002. An additional 16 sites were surveyed only for presence/no detection of amphibians, trout and minnows in 2001.

\section{General}

- Presence/no detection of long-toed salamanders (visual shoreline survey) *

- Presence/no detection of other amphibian species (visual shoreline survey)*

- Presence/no detection of trout species (stocking records, visual shoreline survey) *

- Presence/no detection of minnow species (visual shoreline survey) *

- Beaver activity (historical, current, none evident) (visual survey) *

Aquatic

- Waterbody size (ha)*

- Maximum depth $(\mathrm{m}) *$

- Water temperature $1 \mathrm{~m}$ from shoreline $\left({ }^{\circ} \mathrm{C}\right)$

- Water depth $1 \mathrm{~m}$ from shoreline $(\mathrm{cm})$

- Aquatic substrate ( $\%$ cover in a $1 \mathrm{~m}^{2}$ area)

- Emergent aquatic vegetation type (grass, sedge, rush)

- Density and diversity of zooplankton (samples collected using a $20 \mathrm{~cm}$ diameter zooplankton tow net $5 \mathrm{~m}$ from shore, analyzed in laboratory)

- Density and diversity of macroinvertebrates (1 minute sampling period using a $1 \mathrm{~mm}$ mesh net)

Riparian

- Slope (\%) (slope immediately adjacent to shoreline sampled using a clinometre)

- Distance from shoreline to nearest forest cover (m)

- Degree of human disturbance evident (none, light, moderate, severe)

- Percent cover of shrub species, rock and woody debris $5 \mathrm{~m}$ and $50 \mathrm{~m}$ from shoreline (within two, random $1 \mathrm{~m}^{2}$ areas per $5 \mathrm{~m}$ and $50 \mathrm{~m}$ point)

Multiple regression analysis of all habitat variables and long-toed salamander abundance will be completed after further data collection in 2003. The analysis will examine long-toed salamander associations with selected habitat characteristics.

\subsection{Pond Experiment}

Although little controversy exists regarding the effects of certain fish predators on some amphibians, there is little agreement on the precise mechanisms involved. The use of experimental ponds to evaluate variation in amphibian life histories due to predation and competition is well-established (Figiel, Jr. and Semlitsch, 1990; Tyler et. al., 1998b). The effects of three predators (one rainbow trout fry (Onchorhynchus mykiss), two fathead minnows (Pimephales promelas), two dragonfly larvae (Aeshna sp.)) versus predator-free environments on the survival and growth rate of larval long-toed salamanders were evaluated in a series of $1200 \mathrm{~L}$ plastic tanks (four replicates of each treatment) located within a fenced enclosure at the University of Lethbridge. 
Salamander larvae originated from approximately 700 eggs collected from three adjacent fishless ponds located $6 \mathrm{~km}$ southwest of Beaver Mines, Alberta $\left(49^{\circ} 27^{\prime} \mathrm{N}, 114^{\circ} 12^{\prime} \mathrm{W}\right)$ on $30 \mathrm{May}, 2002$. In brief, the ponds had previously (17 May, 2002) been filled with $1150 \mathrm{~L}$ of irrigation water, $800 \mathrm{~g}$ of air-dried reeds (Typha) and $200 \mathrm{~g}$ of dried leaf material, both of which were collected from the edges of a local pond. One litre innoculations of concentrated zooplankton collected from 3-6 local ponds commenced on 14 June and continued every 14-16 days until the end of the experiment. Zooplankton innoculations were aimed at providing an ad-libitum food source for the salamander larvae and to minimize intraspecific cannibalism (Wildy et al., 2001).

Predator treatments were assigned to the 16 tanks at random. The predators were added to the tanks on 28 June, allowing the larval salamanders (40 individuals per pond) a 7-day acclimation period in the absence of fish and dragonfly larvae. The experiment was concluded on $28 \mathrm{July}$, at the first indication of gill resorption. The survival of all individuals was evaluated as each tank was drained; after which each individual was weighed $( \pm 0.001 \mathrm{~g})$.

\subsection{RESULTS}

\subsection{Distribution Data}

Long-toed salamanders were detected at 68 of the approximately 135 sites surveyed 1993-2002, at elevations from $1275 \mathrm{~m}$ to $2018 \mathrm{~m}$. Appendix A includes coded observation data for each site, including the year that long-toed salamanders were last detected at each location. Thirteen previously unrecorded long-toed salamander breeding locations were documented in 2002 (K. Pearson, unpubl. data). Long-toed salamander presence/no detection data for the region are presented in Figure 3. Site-specific information is considered sensitive and is not included in this report. Site location data is stored with the Regional Endangered Species Biologist, Lethbridge.

\subsection{Long-toed Salamander Habitat Associations}

Selected habitat measurements observed at each of the 27 sites sampled in 2002 are included in Appendix A. Regression analysis of that data is ongoing and the results will be available in Autumn, 2003.

Trout/minnows and long-toed salamanders generally did not co-exist in wetlands in the Castle and Waterton River drainages in 2001-2002. Of the 31 wetlands where long-toed salamanders were observed, $100 \%$ lacked trout and $94 \%$ lacked minnows. Table 2 summarizes the number of locations where long-toed salamanders were present in relation to fish, based on 2001/2002 field surveys. Figure 4 provides a spatial representation of the data in Table 2 . 


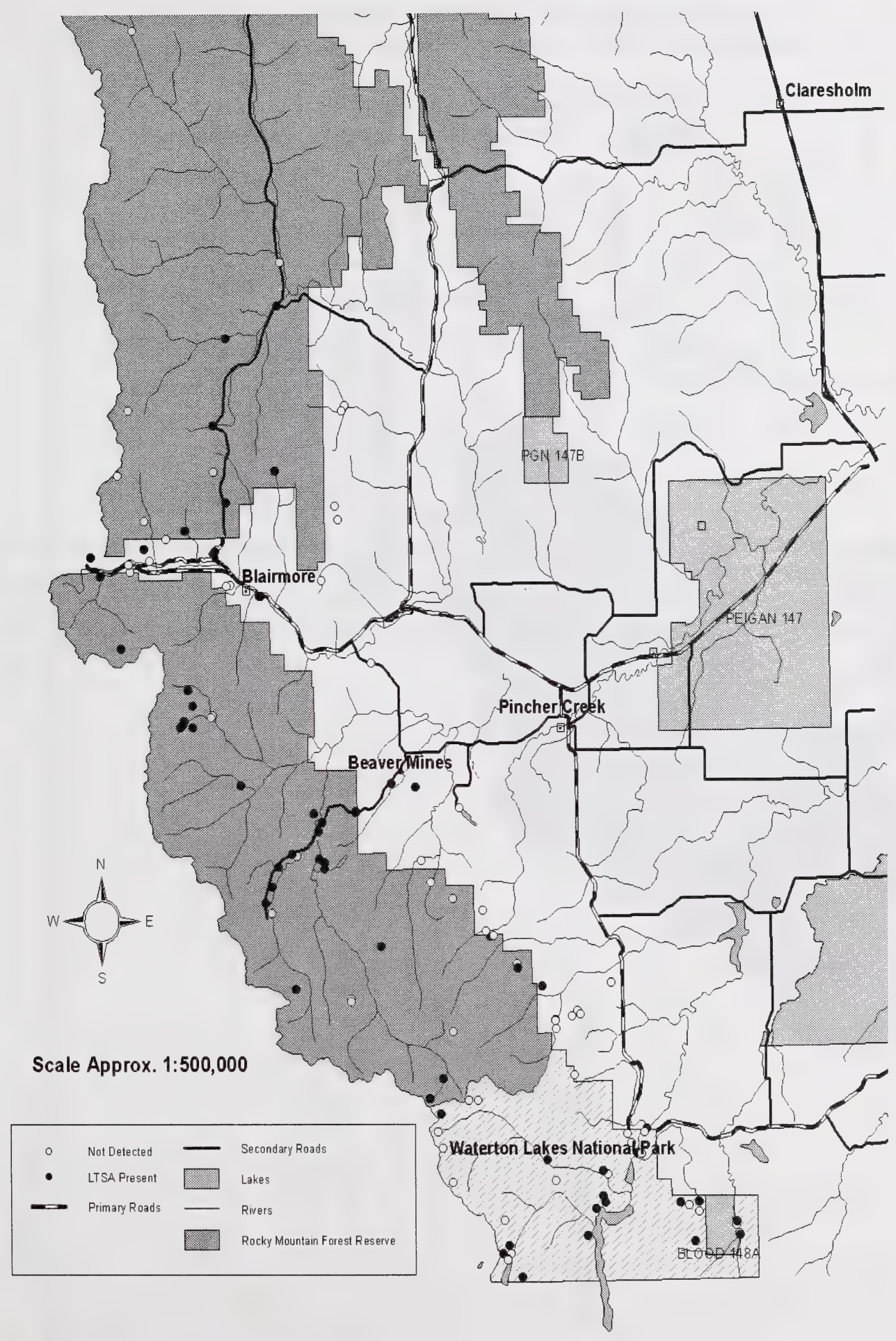

Figure 3. The distribution of long-toed salamanders in the headwaters of the Oldman River drainage, 1993-2002. 


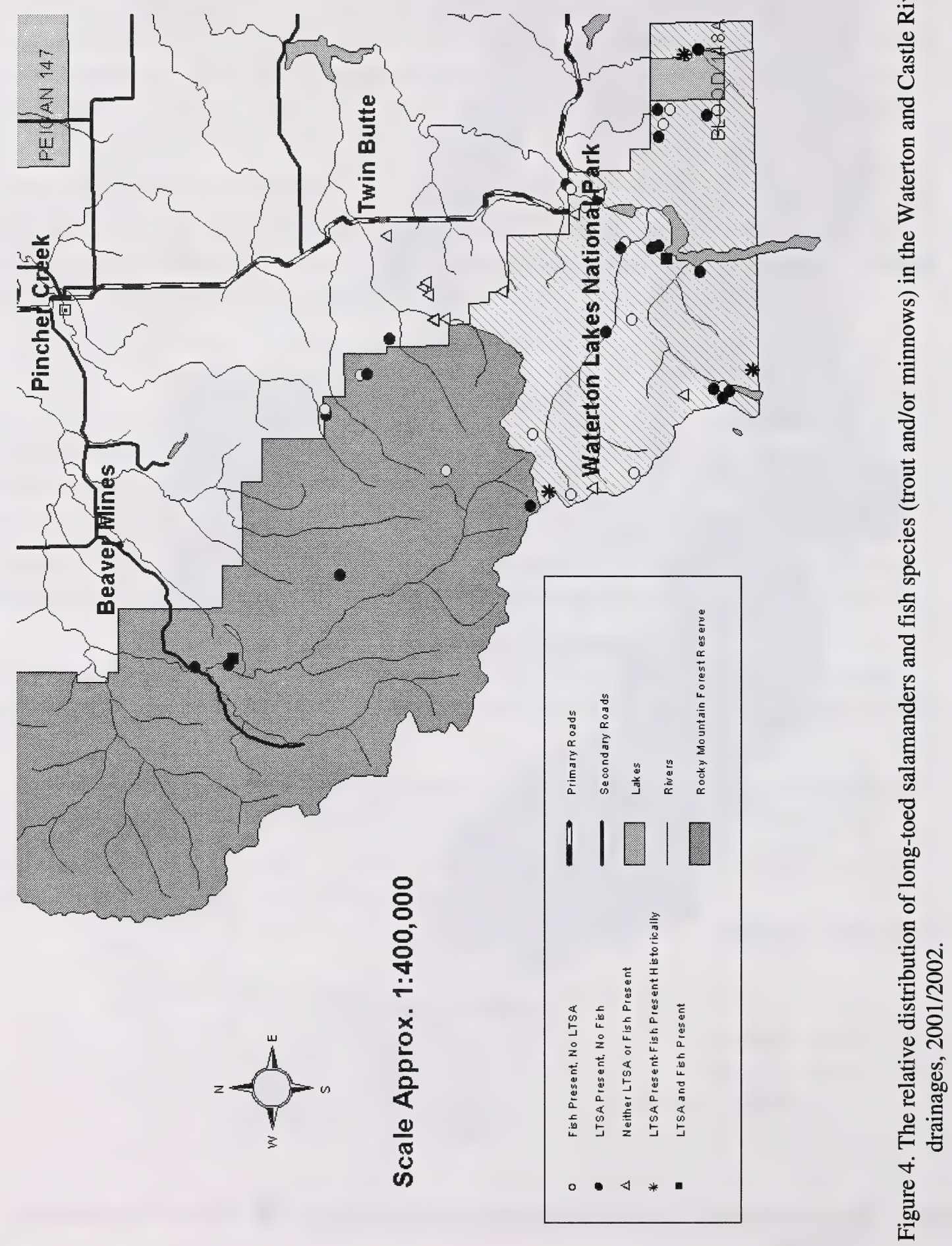


Table 2. Number of sites where long-toed salamanders, trout and minnows were observed in the Waterton and Castle River drainages, 2001-2002.

\begin{tabular}{|c|c|c|c|c|}
\hline $\begin{array}{c}\text { Long-toed } \\
\text { Salamander } \\
\text { Present }\end{array}$ & $\begin{array}{c}\text { Trout } \\
\text { Present }\end{array}$ & $\begin{array}{c}\text { Trout Present } \\
\text { Historically }\end{array}$ & $\begin{array}{c}\text { Minnows } \\
\text { Present }\end{array}$ & \# Sites \\
\hline X & - & - & - & 26 \\
\hline X & X & - & - & 0 \\
\hline- & X & - & - & 10 \\
\hline X & - & X & - & 3 \\
\hline X & - & - & X & 2 \\
\hline- & X & - & X & 6 \\
\hline X & X & - & X & 0 \\
\hline- & - & - & - & 11 \\
\hline & & & Total & 58 \\
\hline
\end{tabular}

\subsection{Pond Experiment}

On average, fewer than $10 \%$ of larval salamanders survived 30 days in the trout and minnow ponds (Figure $5 ; \mathrm{F} 3,15=9.758, \mathrm{P}=0.002$ ), whereas between $25-60 \%$ of the larvae in control and dragonfly ponds survived. Exposure to minnows reduced the mass of larvae by $34-50 \%$ compared to larvae from the other three environments (Figure $6 ; \mathrm{F}_{3,15}=5.574, \mathrm{P}=0.012$ ). Survival of all predators was $100 \%$. 


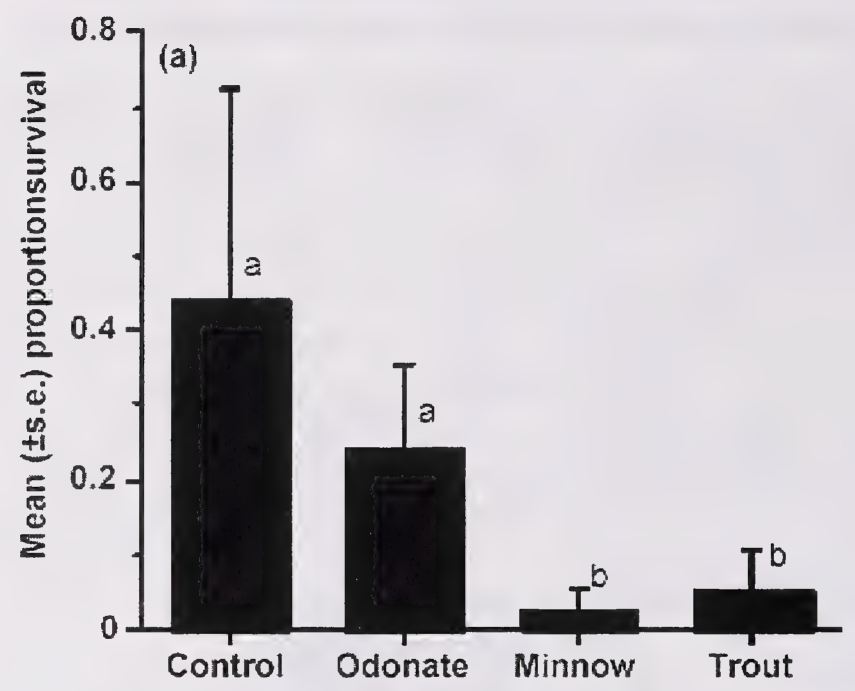

Figure 5. Mean ( \pm s.e.) proportion survival of larval long-toed salamanders reared for 8 weeks in experimental ponds containing dragonfly larvae, minnows, and trout. Pairs of means are significantly different if they do not have the same lower-case letters above the bars.

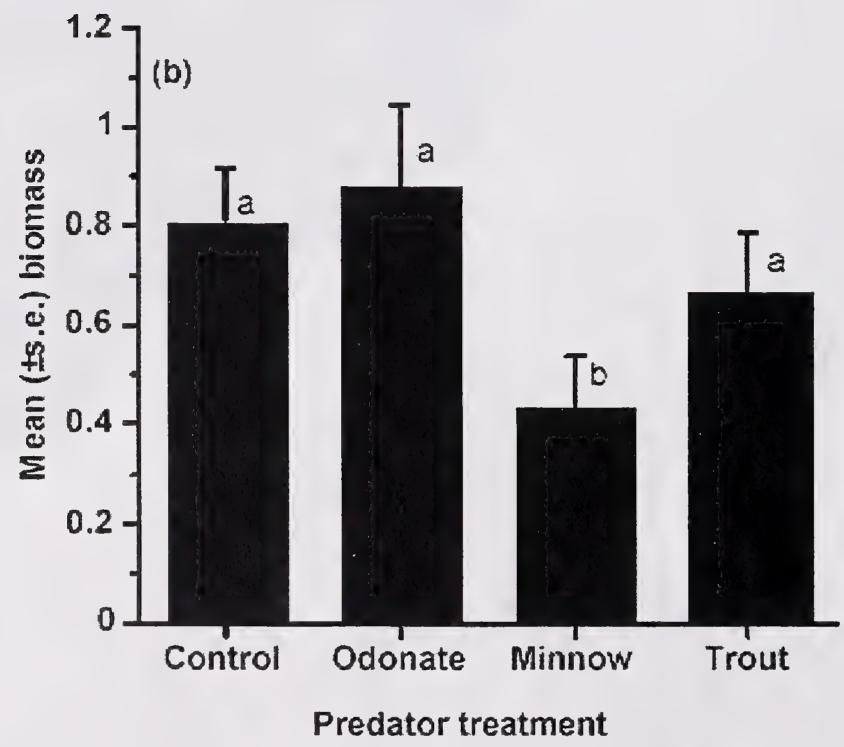

Figure 6. Mean ( \pm s.e.) biomass of larval long-toed salamanders reared for 8 weeks in experimental ponds containing dragonfly larvae, minnows, and trout. Pairs of means are significantly different if they do not have the same lower-case letters above the bars. 


\subsection{DISCUSSION AND RECOMMENDATIONS}

\subsection{Distribution Data}

To date, no long-toed salamander populations have been identified north of Highway 517 to the Highwood Pass area of Kananaskis Country (Paton, 2001; Rose, 2003). The possibility of continuous distribution between the Crowsnest Pass and Kananaskis Country breeding areas, identified by Powell et. al. (1997), has not been thoroughly investigated. Long-toed salamander survey effort in the area north of Highway 517 to Kananaskis Country should be intensified.

Inter-provincial and international collaboration with agencies responsible for long-toed salamander management in British Columbian and Montana should be continued and strengthened.

Management and monitoring of widely-distributed amphibians such as the long-toed salamander should be undertaken on an ecosystem scale.

As shown by Paton (2002), long-toed salamanders have not been recently detected at numerous sites where they were observed in other surveys during the past ten years. This may be a result of a number of factors such as climate, pollution, disease, flooding, habitat alteration, or the interaction of a variety of factors. Discrepancies in timing or methods of surveys may also account for the observed variation.

Based on the unprecedented decline in amphibian populations observed globally since the 1970's, consistent, long-term monitoring of amphibian populations as well as environmental indicators (i.e, $\mathrm{pH}$, water temperature, pollution levels) in the region is imperative to effective management of amphibian populations. Fukumoto (1995) showed that $\mathrm{pH}$ levels of 7 lakes and ponds in Waterton Lakes National Park had decreased by an average of approximately pH 2.25 since 1971. Such acidic conditions have been shown to cause egg mortality in spotted salamanders (Pough, 1976), and other detrimental effects on long-toed salamanders may exist. Given predictions of global climate change (Schindler, 2001), water temperature is another important environmental indicator that should be closely monitored. Numerous studies have documented persistent, unnatural levels of organochlorines and trace metals in subalpine lakes in Banff National Park (Campbell et. al., 2000). Intermittent monitoring of toxic compounds in selected water bodies throughout the headwaters of the Oldman River drainage should be undertaken to provide baseline information regarding their potential impacts on amphibians.

\subsection{Long-toed Salamander Habitat Associations}

As has been observed in Montana by Funk and Dunlap (1999), in Washington State by Tyler et. al. (1998), and in Idaho by Pilliod and Petersen (2001), long-toed salamanders do not appear to co-exist with trout in southwest Alberta. Direct trout predation on salamander larvae is likely the mechanism responsible for the observed exclusion of salamanders from some aquatic habitats (K. Pearson, unpubl. observ.; Tyler et. al. 1998b), while other trout-inhabited waterbodies may be generally unsuitable for breeding salamanders. Of the 15 waterbodies where non-native trout were observed, they were introduced by stocking in 13 locations, and via flooding in the other two locations.

In the interest of ecosystem integrity, specifically amphibian management, fish and wildlife managers should seriously consider cessation of fish stocking in lakes that are likely former longtoed salamander habitats. Lakes with self-perpetuating, introduced fish populations should undergo systematic removal of fish (Parker and Schindler, 2000). Costly long-toed salamander reintroduction programs would not likely be necessary at most sites, as long-toed salamanders have been known to recolonize aquatic habitats from which they were extirpated due to fish stocking (Funk and Dunlap, 
1999). Long-toed salamanders were likely extirpated as a result of past trout stocking in three lakes located in Waterton Lakes National Park (Figure 4). If such extirpations did take place, salamanders have successfully re-colonized those lakes since their fish populations were winterkilled. This is a likely scenario, as all three of the re-colonized lakes are located within three kilometres of historically fishless wetlands that also host breeding salamander populations.

It should be ensured that bullfrogs (Rana catesbiana) are not permitted to colonize Alberta. Studies in California and British Columbia showed that bullfrog population increases were correlated with declines in native frog species (Kiesecker and Blaustein, 1998; Price, 1998). Introduced from Eastern North America circa 1940, the current range of bullfrogs includes the lower mainland and southern Okanagan regions of British Columbia as well as the Bitterroot Mountains of Montana (Price, 1998).

Similarly, the presence of all non-native fishes such as smallmouth bass (Micopterus dolomieui) and goldfish (Carassius auratus) should be closely monitored and controlled. Both of the above-noted species have been shown to negatively affect amphibian species (Kiesecker and Blaustein, 1998; Monello and Wright, 2001).

Results of the ongoing habitat association analysis may be applied by wildlife and aquatic system managers in determining habitats likely occupied by long-toed salamander prior to fish stocking. This information may also facilitate identification of locations in which aquatic ecosystem restoration would benefit native amphibians.

\subsection{Pond Experiment}

The results of our 2002 experiment indicate that minnows have the potential to cause just as great, or greater, a reduction in salamander growth and survival as better-known predators such as trout. This indicates that indirect effects, presumably involving competition for limited zooplankton prey, have the potential to play an important role in causing fish-induced reductions in salamander growth and survival.

In 2002, minnow species and long-toed salamanders were observed within the same water body in two locations, whereas both minnows and trout were observed at six locations where long-toed salamanders were not detected. Though flooding of rivers into amphibian breeding ponds is likely responsible for some minnow introductions, minnows may be introduced (directly or indirectly) to other locations as bait fish (Pearson, unpubl. observ.). Minnow-specific surveys were not conducted in 2002. Rather, minnows were simply noted upon their observation, so there are likely additional locations where minnows were not observed. In 2003, more rigorous minnow surveys are planned to determine the extent to which they may cause conservation implications for amphibians such as the long-toed salamander. 
Possession and use of live bait fish has been restricted in the Bow-Crow Forest Reserve since prior to 1975 . The challenging task of bait fish restriction enforcement should be continued throughout Alberta. The presence of introduced bait fishes in ponds and lakes should be monitored and they should be removed as much as possible. 


\subsection{LITERATURE CITED}

Alberta Sustainable Resource Development (ASRD). 2000. The general status of Alberta wild species 2000. Alberta Sustainable Resource Development, Fish and Wildlife Service. Edmonton, AB. 46 pp.

Alford, R.A. and S.J. Richards. 1999. Global amphibian declines: a problem in applied ecology. Ann. Rev. Ecol. Syst. 30:133-166.

Bradford, D.F. 1989 Allopatric distribution of native frogs and introduced fishes in high Sierra Nevada lakes of California: implications of the negative effect of fish introductions. Copeia 1989:775-778.

Bradford, D.F. and D.M. Graber. 1993. Isolation of remaining populations of the native frog, Rana muscosa, by introduced fishes in Sequoia and Kings Canyon National Parks, California. Conservation Biology 7:882-888.

Campbell, L.M., D.W. Schindler, D.B. Donald and D.C.G. Muir. 2000. Organochlorine transfer in the food web of subalpine Bow Lake, Banff National Park. Can. J. Fish. Aquat. Sci. 57:1-12.

Donald, D.B. 1987. Assessment of the outcome of eight decades of trout stocking in the Mountain National Parks, Canada. North Am. J. Fish. Mgmt. 7:545-553.

Figiel, Jr., C.R. and R.D. Semlitsch. 1990. Population variation in survival and metamorphosis of larval salamanders (Ambystoma maculatum) in the presence and absence of fish predation. Copeia 1990:818-826.

Fukumoto, J. 1995. Long-toed salamander (Ambystoma macrodactylum) ecology and management in Waterton Lakes National Park. Master's Degree Thesis. The University of Calgary, Calgary, AB. 108 pp.

Funk, W.C. and W.W. Dunlap. 1999. Colonization of high-elevation lakes by long-toed salamanders (Ambystoma macrodactylum) after the extinction of introduced trout populations. Can. J. Zool. 77:1759-1767.

Graham, K.L. and G.L. Powell. 1999. Status of the long-toed salamander (Ambystoma macrodactylum) in Alberta. Alberta Environmental Protection, Fisheries and Wildlife Management Division, and Alberta Conservation Association, Wildlife Status Report No. 22, Edmonton, AB. 19 pp.

Holroyd, G.L. and K.J. Van Tighem. 1983. Ecological (Biophysical) Land Classification of Banff and Jasper National Parks. Vol. III: The Wildlife Inventory. Prepared by Canadian Wildlife Service for Parks Canada Western Region, Environment Canada. Edmonton, AB. 444 pp.

Huynh, M., L. Takats and L. Wilkinson. 2002. Long-toed salamander (Ambystoma macrodactylum) monitoring study in Alberta: summary report 1998-2001. Alberta Sustainable Resource Development, Fish and Wildlife Division, Alberta Species at Risk Report No. 36. Edmonton, AB. 34 pp. 
Kats, L. B. and A. Sih.1992. Oviposition site selection and avoidance of fish by streamside salamanders (Ambystoma barbouri). Copeia 1992:468-473.

Kiesecker, J.M. and A.R. Blaustein. 1998. Effects of introduced bullfrogs and smallmouth bass on microhabitat use, growth and survival of native red-legged frogs (Rana aurora). Conserv. Biol. 12:776-787.

Matthews, K.R. K.L. Pope, H.K. Preisler, and R.A. Knapp. 2001. Effects of nonnative trout on Pacific treefrogs (Hyla regilla) in the Sierra Nevada. Copeia 2001:1130-1137.

Monello, R. J. and R. G. Wright. 2001. Predation by goldfish (Carassius auratus) on eggs and larvae of the eastern long-toed salamander (Ambystoma macrodactylum columbianum). J. Herpetol. 35:350-353.

Nelson S.J., G.L. Powell, and A.P. Russell. 1995. Population survey of the long-toed salamander (Ambystoma macrodactylum) in southwestern Alberta. Alberta Environmental Protection, Natural Resources Services, Wildlife Management Division. $226 \mathrm{pp}$.

Oseen, K., G.L. Powell and A.P. Russell. 1995. The distribution of long-toed salamander (Ambystoma macrodactylum) in southwestern Alberta. Alberta Environmental Protection, Fish and Wildlife Service, Edmonton, AB. 67 pp.

Parker, B.R. and D.W. Schindler. 2000. Square hooks for exotic brooks: Experimental gillnet removal of brook trout from Bighorn Lake, Banff National Park. Research Links 8:1, 7 \& 11.

Paton, D. 2002. Columbian mountain amphibian surveys, 2001. Alberta Sustainable Resource Development, Fish and Wildlife Division, Alberta Species at Risk Report No. 39. Edmonton, AB. 15 pp.

Pearson, K.J. 2001. Waterton Lakes National Park ecological monitoring program summary, 1997-2001. Unpublished Technical Report. Parks Canada, Waterton Park, Alberta. 56 pp.

Pilliod, D. S. and C. R. Peterson. 2001. Local and landscape effects of introduced trout on amphibians in historically fishless watersheds. Ecosystems 4:322-333.

Pough, F.H. 1976. Acid precipitation and embryonic mortality of spotted salamanders, Ambystoma maculatum. Science 192:68-70.

Powell, G.L., A.P. Russell, S.J. Nelson, I.M. Hamilton and K.L. Graham. 1997. The status of the long-toed salamander (Ambystoma macrodactylum) in Alberta. Alberta Environmental Protection, Fish and Wildlife Service, Edmonton, AB. 135 pp.

Price, P. 1998. Survey of Bullfrogs (Rana catesbeiana) in British Columbia. Department of Biology, University of Victoria. Victoria, B.C., Canada. http://web.uvic.ca/bullfrogs/ (4 January 2003). 
Schindler, D.W. 2001. The cumulative effects of climate warming and other human stresses on Canadian freshwaters in the new millennium Can. J. Fish. Aquat. Sci. 58:18-29.

Resetarits Jr., W.J., and H.M. Wilbur. 1991. Calling site choice by Hyla chrysolscelis: effect of predators, competitors, and oviposition sites. Ecology 72:778-786.

Rose, S. 2003. Personal communication. Alberta Conservation Association, Recording Amphibian Numbers in Alberta (RANA) Kananaskis Project, Calgary, AB.

Thoms, C., C.C. Corkran, and D.H. Olson. 1997. Basic amphibian survey for inventory and monitoring in lentic habitats. In Sampling amphibians in lentic habitats. Edited by D. Olson, W. Leonard, and R. Bury. Society for Northwestern Vertebrate Biology, Olympia, Wash. Pp. 35-46.

Thompson, M.D. 2000. Phylogeography of Ambystoma macrodactylum. Field summary report \#2 2000. Unpublished Technical Report. Department of Biological Sciences, University of Calgary, Calgary, Alberta. 51 pp.

Tyler, T., W. J. Liss, L. M. Ganio, G. L. Larson, R. Hoffman, E. Deimling, and G. Lomnicky 1998. Interaction between introduced trout and larval salamanders (Ambystoma macrodactylum) in high-elevation lakes. Conserv. Biol. 12:94-105.

Tyler, T., W. J. Liss, R. Hoffman, and L. M. Ganio. 1998b. Experimental analysis of trout effects on survival, growth and habitat use of two species of Ambystomatid salamanders. J. Herpetol. 32:345-349.

Wallis, C., C. Wershler and R. Riddell. 2002. Ecological land classification of Waterton Lakes National Park. Volume 2. Wildlife resources. Parks Canada, Waterton Park, AB.

Wildy, E. M., D. P. Chivers, J. M. Kiesecker, and A. R. Blaustein. 2001. The effects of food level and conspecific density on biting and cannibalism in larval long-toed salamanders, ambystoma macrodactylum. Oecologia 128:202-209.

Zimmer, K.D., M.A. Hanson, and M.G. Butler. 2000. Factors influencing invertebrate communities in prairie wetlands: a multivariate approach. Can. J. Fish. Aquat. Sci. 57:76-85. 


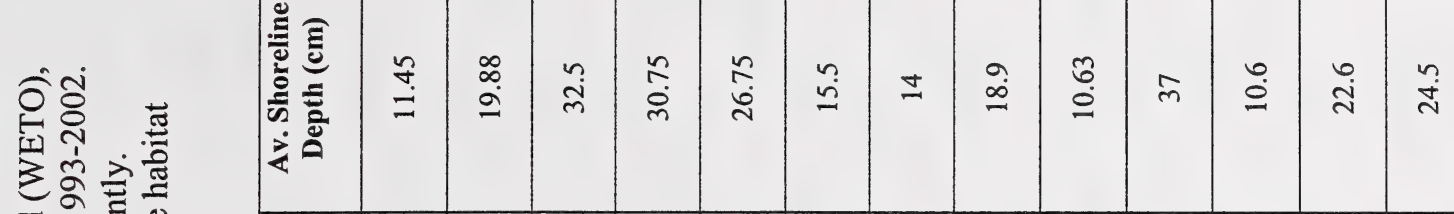
ซ

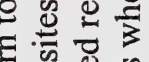

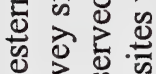

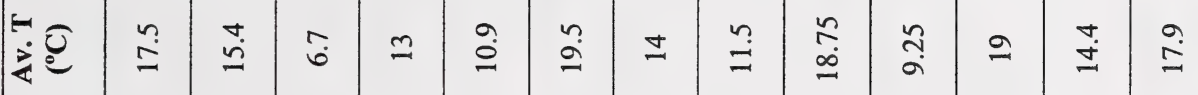

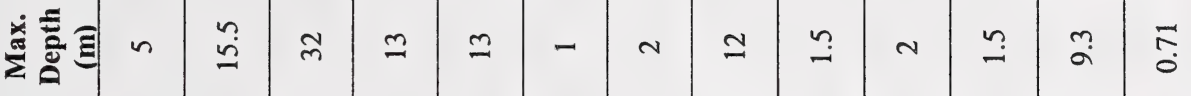
\&

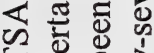
을 $=\ll$ 일 芯 吾

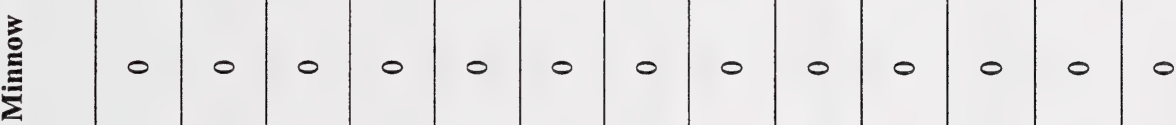
की

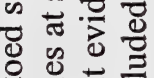
$\frac{0}{1} \cdot \frac{0}{0} \frac{0}{0}$ 으 을 힌

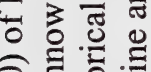

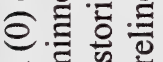
으를 흘

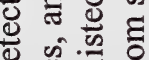
क्षे 이요 की छ च 층 응

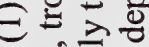

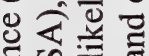
记

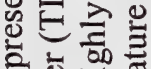

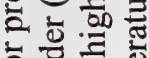
흘 흥 ठ है छี

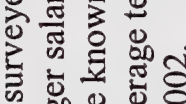
ชै: ప స के \begin{tabular}{|l|l|l|l|l|l|l|l|l|l|l|l|l}
\hline$\Xi$ \\
\hline
\end{tabular} \begin{tabular}{llllll|l|l|l|l|l|l|l|l|l}
$\mathbb{E}$ & 0 & 0 & 0 & 0 & 0 & 0 & 0 & 0 & 0 & 0 & 0 & 0 & 0
\end{tabular}

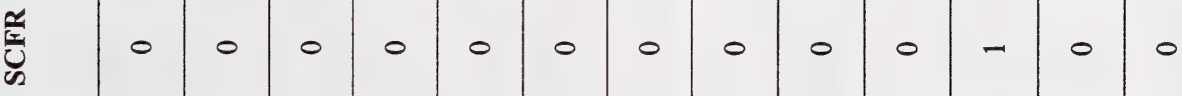
\begin{tabular}{ll|l|l|l|l|l|l|l|l|l|l|l|l}
\hline$\frac{1}{n}$ & - & 0 & 0 & 0 & 0 & 0 & - & 0 & - & 0 & - & 0 & 0
\end{tabular} \begin{tabular}{lll|l|l|l|l|l|l|l|l|l|l|l}
0 & - & 0 & 0 & 0 & 0 & - & 0 & - & 0 & 0 & - & 0 & 0 \\
\hline
\end{tabular}

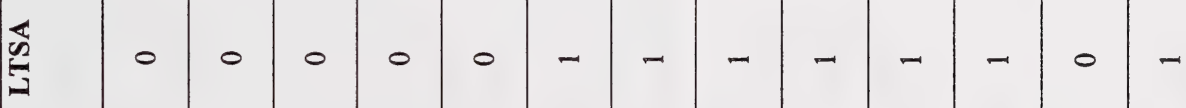

可

芯芯

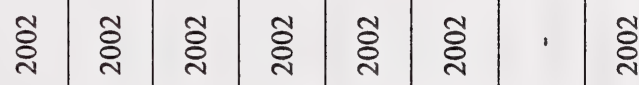
$\circ \frac{1}{2}$ थ ह

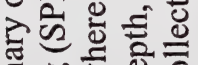
\&

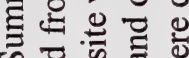
थ

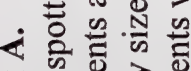
흥 Ð 틀 흥율

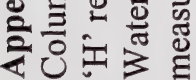

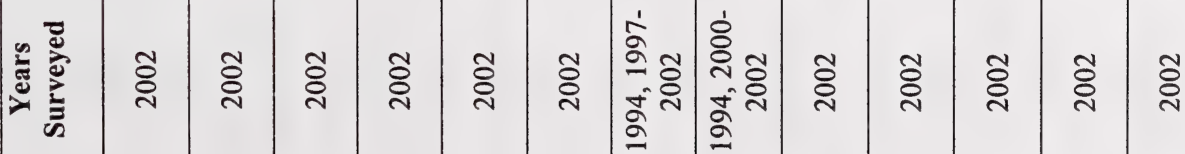
踣

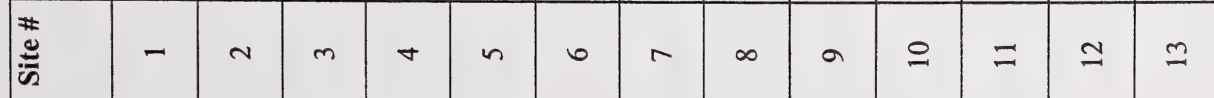




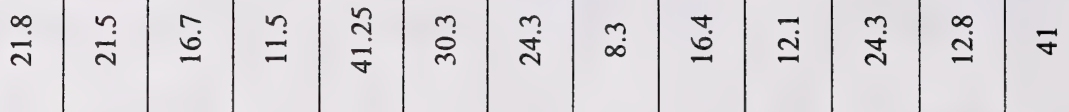

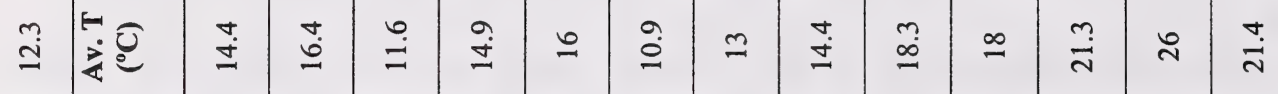

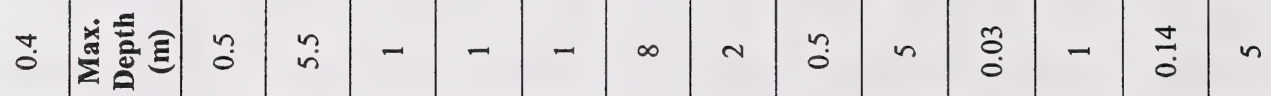

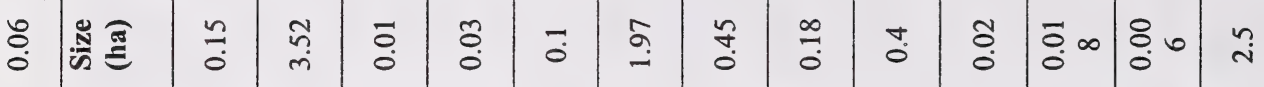

$-\quad 0$ -

\begin{tabular}{l|l|l|l|l|l|l|l|l|l|l|l|l|l|l}
- & 0 & I & 0 & 0 & 0 & 0 & $I$ & 0 & 0 & - & 0 & 0 & 0 & -
\end{tabular}

\begin{tabular}{l|l|l|l|l|l|l|l|l|l|l|l|l|l|l|l}
\hline & 0 & - & 0 & 0 & 0 & 0 & 0 & 0 & 0 & 0 & 0 & 0 & 0 & 0 & 0
\end{tabular}

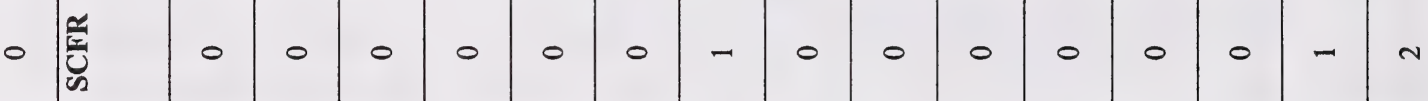

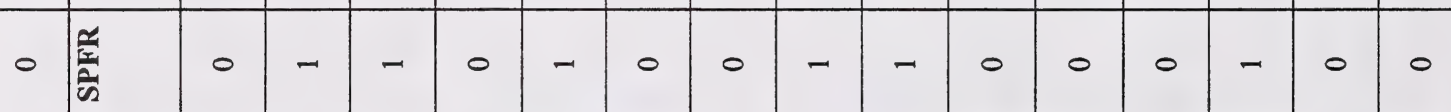

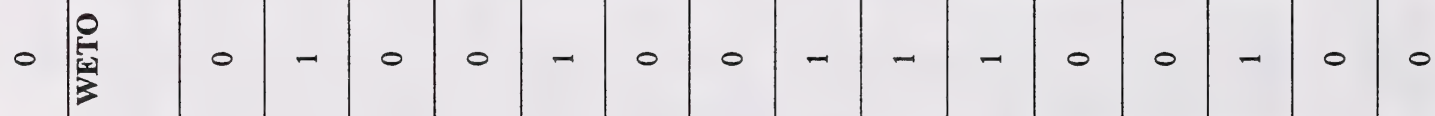

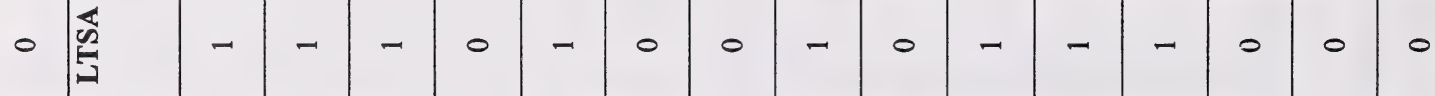

)

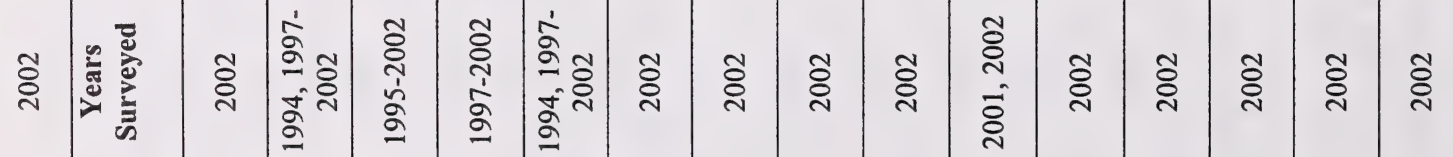

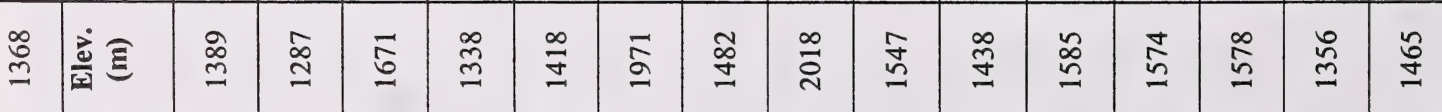

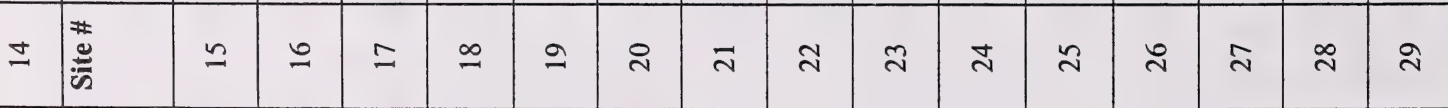




\begin{tabular}{|c|c|c|c|c|c|c|c|c|c|c|c|c|c|c|c|c|}
\hline ' & ' & 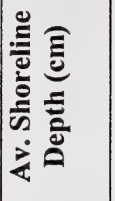 & ' & ' & ' & ' & ' & ' & ' & ' & ' & ' & ' & ' & ' & ' \\
\hline ' & ' & $\begin{array}{l}1 \\
\dot{2} 0 \\
0\end{array}$ & ' & ' & ' & ' & ' & ' & ' & ' & ' & ' & ' & ' & ' & ' \\
\hline ' & ' & 这 & ' & ' & ' & ' & ' & ' & ' & ' & ' & ' & ' & ' & ' & ' \\
\hline ' & ' & 谒 & ' & ' & ' & ' & ' & ' & 1 & ' & ' & ' & ' & ' & ' & ' \\
\hline 0 & 0 & 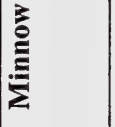 & 0 & 0 & 0 & 0 & - & 0 & 0 & 0 & - & 0 & 0 & 0 & 0 & 0 \\
\hline 0 & 0 & Ë & 0 & 0 & 0 & 0 & 0 & 0 & 0 & 0 & - & 0 & - & 0 & $I$ & - \\
\hline- & 0 & 低 & 0 & 0 & 0 & 0 & 0 & - & 0 & 0 & 0 & 0 & 0 & - & 0 & 0 \\
\hline 0 & 0 & 竞 & 0 & 0 & 0 & 0 & 0 & 0 & - & 0 & 0 & 0 & 0 & - & 0 & 0 \\
\hline- & 0 & $\frac{x}{\frac{1}{2}}$ & - & - & - & 0 & - & - & - & 0 & 0 & 0 & 0 & 0 & - & - \\
\hline- & 0 & 总 & 0 & 0 & - & - & - & 0 & 0 & 0 & 0 & 0 & 0 & - & - & - \\
\hline 0 & 0 & 造 & - & - & - & - & - & 0 & 0 & - & 0 & - & 0 & - & - & 0 \\
\hline ' & ' & 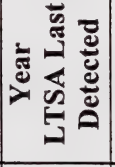 & ర్రి & ర్ & రి & రิ & ర్లి & ' & ' & ర్ & ' & ర్ & ' & §ิ & ర్ & ' \\
\hline ర్ & ర్రి & 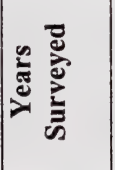 & రి & రి & 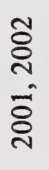 & రి & 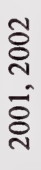 & ઠิ & ઠิ & ర్ & ઠิ & ชิ & ธิ & 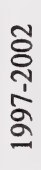 & 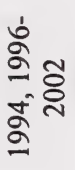 & 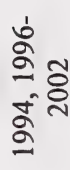 \\
\hline I & $\underset{\infty}{\infty}$ & 远 & $\frac{n}{6}$ & $\frac{\Xi}{\Xi}$ & 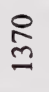 & 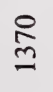 & $\stackrel{m}{ \pm}$ & $\underset{\infty}{\Xi}$ & $\underset{\infty}{ \pm}$ & $\underset{\sim}{\approx}$ & 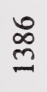 & હે & శ్ & ஓ् & ్లి & $\stackrel{ल}{\varrho}$ \\
\hline ్ల & $\bar{m}$ & 茪 & ๗ี & $m$ & ले & $\approx$ & b & $\hat{m}$ & $\stackrel{\infty}{m}$ & ले & P & $\bar{\nabla}$ & ㄱ & F & ষ & $\vartheta$ \\
\hline
\end{tabular}




\begin{tabular}{|c|c|c|c|c|c|c|c|c|c|c|c|c|c|c|c|c|}
\hline ' & ' & ' & 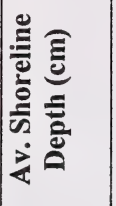 & ' & ' & ' & ' & ' & ' & ' & ' & ' & ' & ' & ' & ' \\
\hline ' & ' & ' & 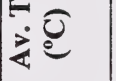 & ' & ' & ' & ' & ' & ' & ' & ' & ' & ' & ' & ' & ' \\
\hline ' & ' & ' & 离 & ' & . & ' & ' & ' & ' & ' & ' & ' & ' & . & ' & ' \\
\hline I & ' & ' & 芯 & 1 & ' & ' & ' & ' & ' & ' & ' & ' & . & ' & ' & ' \\
\hline 0 & 0 & 0 & 疍 & 0 & 0 & 0 & 0 & 0 & I & $I$ & $I$ & 0 & 0 & ' & ' & ' \\
\hline 0 & 0 & I & E & 0 & 0 & 0 & 0 & 0 & II & $I$ & $I$ & 0 & 0 & ' & ' & ' \\
\hline 0 & - & 0 & 造 & 0 & - & - & 0 & 0 & 0 & 0 & 0 & 0 & 0 & 0 & 0 & 0 \\
\hline 0 & - & 0 & $\frac{a}{c}$ & 0 & - & - & 0 & - & - & 0 & 0 & - & 0 & ' & ' & ' \\
\hline - & 0 & - & $\frac{a}{\frac{\pi}{n}}$ & - & $\Rightarrow$ & - & 0 & 0 & 0 & - & - & 0 & - & 0 & - & - \\
\hline- & - & - & 인 & - & - & - & - & 0 & 0 & - & - & 0 & 0 & 0 & - & 0 \\
\hline- & - & - & 选 & - & - & - & 0 & 0 & 0 & 0 & 0 & 0 & - & - & - & - \\
\hline 휴 & 휴 & ઠิ & 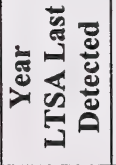 & ڤे & ฐั & Бே & ' & ' & ' & ' & ' & ' & Бे & $\approx$ & ¿্ & ষ্ণ \\
\hline 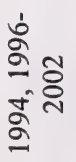 & 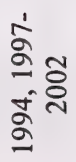 & 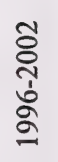 & 吾 & $\begin{array}{l}\text { ठิ } \\
\text { స̆ } \\
\text { ळू }\end{array}$ & 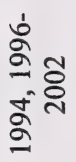 & 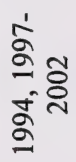 & ஓ्্ & $\begin{array}{l}\text { \&̊ } \\
\text { ஸे } \\
\frac{1}{2}\end{array}$ & 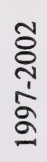 & $\begin{array}{l}\text { ঠั } \\
\text { } \\
\frac{1}{2} \\
\text { }\end{array}$ & 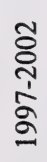 & Бั & 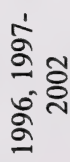 & $\begin{array}{l}\overline{8} \\
\text { ஸू } \\
\text { ळ }\end{array}$ & $\begin{array}{l}\bar{\delta} \\
\text { ई } \\
\text { ळ }\end{array}$ & $\begin{array}{l}\overline{8} \\
\text { ஃे } \\
\text { ஃ }\end{array}$ \\
\hline$\stackrel{\text { }}{=}$ & ঠ & $\stackrel{\infty}{=}$ & 它 & 욤 & $\stackrel{n}{n}$ & $\stackrel{2}{2}$ & $\stackrel{\mathscr{2}}{\varrho}$ & $\stackrel{8}{\text { ¿ }}$ & $\stackrel{\infty}{\underset{1}{0}}$ & ஜ & 은 & $\approx$ & ஜ & 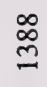 & $\frac{+}{6}$ & $\approx$ \\
\hline $\mathscr{f}$ & $\hat{\forall}$ & $\stackrel{\infty}{+}$ & \# & $\stackrel{\partial}{\forall}$ & 으 & $\bar{n}$ & $\approx$ & $\tilde{n}$ & 棺 & $\approx$ & & $n$ & $\stackrel{\infty}{\sim}$ & ฉิ & 8 & $\bar{\sigma}$ \\
\hline
\end{tabular}




\begin{tabular}{|c|c|c|c|c|c|c|c|c|c|c|c|c|c|c|c|c|}
\hline ' & ' & ' & ' & 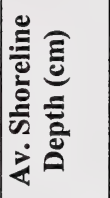 & ' & ' & ' & ' & ' & ' & ' & ' & ' & ' & ' & ' \\
\hline ' & ' & ' & ' & 苞它 & , & ' & ' & ' & ' & ' & ' & ' & ' & 1 & ' & ' \\
\hline ' & ' & ' & ' & 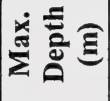 & ' & ' & ' & ' & ' & ' & ' & ' & ' & ' & ' & ' \\
\hline , & י & , & ' & 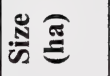 & ' & ' & ' & ' & ' & ' & ' & ' & ' & ' & ' & ' \\
\hline ' & ' & ' & ' & 产 & ' & ' & ' & 1 & ' & ' & ' & ' & ' & ' & ' & ' \\
\hline ' & ' & ' & ' & Ë & ' & ' & ' & ' & ' & ' & ' & ' & ' & ' & ' & ' \\
\hline 0 & - & 0 & 0 & $\underset{\mathscr{N}}{\mathscr{E}}$ & 0 & 0 & 0 & 0 & 0 & 0 & 0 & 0 & 0 & 0 & 0 & 0 \\
\hline ' & ' & ' & ' & 雍 & ' & ' & ' & ' & ' & ' & ' & ' & ' & ' & ' & ' \\
\hline 0 & 0 & 0 & 0 & $\frac{\frac{x}{x}}{\frac{1}{n}}$ & 0 & - & 0 & 0 & 0 & - & - & - & 0 & 0 & 0 & 0 \\
\hline 0 & 0 & 0 & 0 & 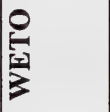 & 0 & 0 & 0 & 0 & 0 & 0 & - & - & 0 & - & 0 & 0 \\
\hline- & - & - & - & 选 & - & 0 & - & - & - & - & - & - & - & - & 0 & - \\
\hline 气 & 휴 & ్ㅜㅇ & ๙ & 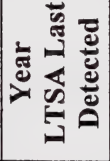 & ڤ̆ & , & ๙ & 휴 & ๙ั & ฉू & চ্ণ & ๙ू & ڤ̆ & 气ू & ' & 홍 \\
\hline 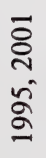 & 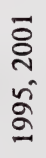 & 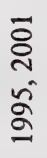 & 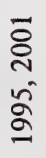 & : & $\begin{array}{l}\overline{8} \\
\text { ¿ } \\
\text { ڤ }\end{array}$ & 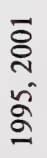 & $\begin{array}{l}\overline{8} \\
\text { ஸे } \\
\check{2}\end{array}$ & 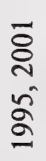 & $\begin{array}{l}\overline{8} \\
\text { ळे } \\
\text { ڤ }\end{array}$ & 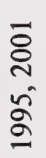 & $\begin{array}{l}\bar{\delta} \\
\text { ळ } \\
\text { ळ }\end{array}$ & $\begin{array}{l}\overline{8} \\
\text { ळ. } \\
\text { ๙ }\end{array}$ & $\begin{array}{l}\overline{8} \\
\text { ڤ } \\
\text { ळ }\end{array}$ & $\begin{array}{l}\overline{8} \\
\text { ळ } \\
\text { ळ }\end{array}$ & $\begin{array}{l}\overline{8} \\
\text { ळ } \\
\text { ळ }\end{array}$ & 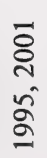 \\
\hline ๙ૂ & $\stackrel{n}{\cong}$ & $\stackrel{\simeq}{\cong}$ & $\cong$ & 远 & $\begin{array}{l}\infty \\
\infty \\
\end{array}$ & $\stackrel{\Xi}{ \pm}$ & $\tilde{m}$ & $\stackrel{\circ}{\Xi}$ & $\check{m}$ & $\stackrel{m}{\tilde{m}}$ & ๓ิ & $\hat{\check{2}}$ & $\stackrel{\infty}{\sim}$ & $\begin{array}{l}\infty \\
\stackrel{\infty}{=}\end{array}$ & $\stackrel{\circ}{\cong}$ & 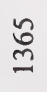 \\
\hline ชె & $\tilde{6}$ & J & $\approx$ & 泀 & 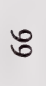 & $\widehat{6}$ & $\infty$ & 8ิ & 우 & $\bar{\nabla}$ & $\mathbb{N}$ & $\stackrel{m}{r}$ & $\underset{\sim}{\mathbb{N}}$ & $\approx$ & $\stackrel{2}{2}$ & $\approx$ \\
\hline
\end{tabular}




\begin{tabular}{|c|c|c|c|c|c|c|c|c|c|c|c|c|c|c|c|c|}
\hline . & ' & ' & ' & ' & 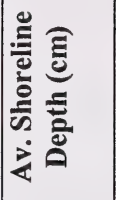 & ' & ' & . & ' & ' & ' & ' & ' & ' & ' & ' \\
\hline ' & ' & ' & ' & ' & 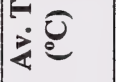 & ' & ' & ' & ' & ' & ' & ' & ' & ' & ' & ' \\
\hline ' & ' & ' & ' & ' & 远芯 & ' & ' & ' & ' & 1 & ' & ' & ' & ' & ' & . \\
\hline . & ' & ' & ' & ' & 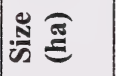 & ' & ' & ' & ' & ' & ' & ' & ' & ' & ' & ' \\
\hline ' & ' & ' & ' & ' & 旁 & ' & ' & 1 & ' & ' & ' & ' & ' & ' & ' & ' \\
\hline ' & ' & I & ' & ' & 㺼 & ' & ' & ' & ' & ' & ' & ' & 1 & ' & 1 & ' \\
\hline 0 & 0 & 0 & 0 & 0 & $\underset{\mathscr{Z}}{\mathbb{E}}$ & 0 & 0 & 0 & 0 & 0 & 0 & 0 & 0 & 0 & 0 & 0 \\
\hline ' & 1 & ' & ' & ' & $\frac{\pi}{\widetilde{c}}$ & ' & ' & ' & ' & ' & ' & ' & ' & ' & ' & ' \\
\hline- & 0 & 0 & 0 & 0 & $\frac{x}{\frac{x}{\Sigma}}$ & - & 0 & 0 & 0 & 0 & - & 0 & - & 0 & - & 0 \\
\hline- & 0 & 0 & - & 0 & 战 & 0 & 0 & - & 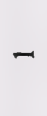 & 0 & 0 & 0 & 0 & - & 0 & 0 \\
\hline- & 0 & - & - & 0 & W & 0 & 0 & 0 & 0 & - & 0 & - & - & 0 & 0 & - \\
\hline চ্ণ & ' & ๙ু & চ্ণ & $\approx$ & 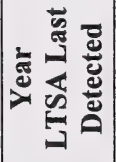 & ๙ & ळ & $\approx$ & ๙ & 유 & ' & চ্ণ & ஓ्తి & ' & ' & ¿্ं \\
\hline $\begin{array}{l}\overline{8} \\
\text { ते } \\
\text { ๙ }\end{array}$ & 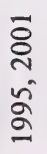 & 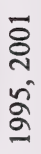 & $\begin{array}{l}\overline{8} \\
\text { ๙ } \\
\text { ๙ }\end{array}$ & ๙ू & 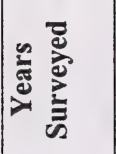 & ๙ & $\check{2}$ & ๙ू & ลू & 휴 & 유 & চ্ণ & চ্ণ & চ্ণ & ్ㅗㅇ & ষ্ণ \\
\hline$\stackrel{m}{m}$ & $\frac{ \pm}{2}$ & $\stackrel{2}{\varrho}$ & 음 & $\stackrel{8}{0}$ & 远 $\widehat{E}$ & ' & 1 & ' & ' & ' & ' & 1 & ' & 1 & ' & I \\
\hline$\stackrel{\infty}{\sim}$ & 2 & $\triangleright$ & $\bar{\infty}$ & ळ & 苋 & $\infty$ & ষ & $\infty$ & $\infty$ & $\infty$ & $\infty$ & ळे & ㅇ & $\bar{a}$ & สู & $\tilde{\sigma}$ \\
\hline
\end{tabular}




\begin{tabular}{|c|c|c|c|c|c|c|c|c|c|c|c|c|c|c|c|c|}
\hline ' & ' & . & ' & ' & ' & 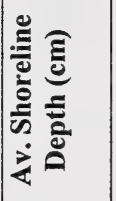 & ' & ' & ' & ' & ' & ' & ' & ' & ' & ' \\
\hline ' & ' & ' & ' & ' & ' & $\stackrel{0}{*}$ & ' & ' & ' & ' & . & 1 & ' & ' & ' & ' \\
\hline ' & ' & ' & ' & ' & ' & 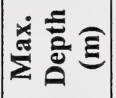 & ' & ' & ' & ' & ' & ' & ' & ' & ' & ' \\
\hline ' & ' & ' & ' & ' & ' & 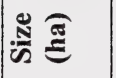 & ' & , & ' & ' & 1 & ' & ' & ' & ' & ' \\
\hline ' & ' & ' & ' & ' & ' & 竭 & ' & ' & ' & ' & ' & ' & ' & ' & ' & ' \\
\hline ' & ' & ' & I & ' & ' & E & ' & ' & ' & ' & ' & ' & ' & ' & ' & ' \\
\hline 0 & 0 & 0 & 0 & 0 & 0 & 造 & 0 & 0 & 0 & 0 & 0 & 0 & 0 & 0 & 0 & - \\
\hline ' & ' & ' & ' & ' & ' & U⿺ & ' & ' & ' & 1 & ' & ' & 1 & ' & 1 & ' \\
\hline- & 0 & - & 0 & 0 & - & $\frac{r}{\omega}$ & - & 0 & - & 0 & 0 & 0 & - & - & 0 & 0 \\
\hline- & - & 0 & 0 & 0 & 0 & 0 & 0 & 0 & - & - & 0 & 0 & - & 0 & 0 & 0 \\
\hline 0 & 0 & - & - & - & 0 & $\underset{\mathscr{W}}{\mathbb{2}}$ & - & - & - & 0 & - & - & 0 & 0 & - & 0 \\
\hline ' & ' & 휴 & ষ্ণ & 홍 & ' & 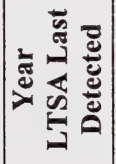 & $\overline{\check{~}}$ & চ্ণ & ঠ్రి & ' & 호 & 휴 & ' & ' & ষ্ণ & ' \\
\hline 유 & 휴 & 홍 & ஓ्ন & ఠ్ & Б्) & 竞 & 휴 & ठ্ণ & 홍 & ஓ్ & ఠ్ & 휴 & 훙 & 휴 & ஓ్ & ৪্ \\
\hline ' & ' & ' & ' & ' & ' & 总 & ' & ' & ' & ' & ' & 1 & ' & ' & , & ' \\
\hline ন゙ & $\approx$ & ถำ & $\hat{a}$ & $\stackrel{\circ}{\circ}$ & ฉે & 范 & \& & 으 & ฮิ & $\underline{\varrho}$ & $\underset{\Xi}{ \pm}$ & $\cong$ & 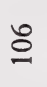 & 。 & $\stackrel{\infty}{\circ}$ & 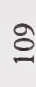 \\
\hline
\end{tabular}




\begin{tabular}{|c|c|c|c|c|c|c|c|c|c|c|c|c|c|c|c|c|}
\hline . & ' & ' & ' & ' & ' & ' & 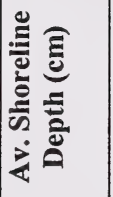 & ' & ' & ' & ' & ' & 1 & ' & $\therefore$ & I \\
\hline ' & . & ' & ' & ' & ' & ' & 安包 & ' & ' & ' & . & ' & ' & ' & ' & ' \\
\hline ' & ' & ' & ' & ' & ' & ' & 远 & ' & ' & ' & ' & ' & ' & ' & ' & ' \\
\hline ' & ' & ' & ' & ' & ' & ' & 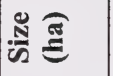 & ' & ' & 1 & ' & ' & ' & ' & ' & ' \\
\hline ' & ' & ' & ' & ' & ' & ' & 言 & ' & ' & ' & ' & ' & ' & ' & ' & ' \\
\hline ' & ' & ' & ' & ' & ' & ' & 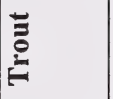 & ' & ' & ' & ' & ' & ' & ' & ' & ' \\
\hline 0 & 0 & 0 & 0 & 0 & 0 & 0 & & 0 & 0 & 0 & 0 & 0 & 0 & 0 & 0 & 0 \\
\hline ' & ' & ' & ' & ' & ' & ' & 丞 & 0 & 0 & 0 & 0 & 0 & 0 & 0 & 0 & 0 \\
\hline 0 & 0 & 0 & 0 & 0 & 0 & - & $\frac{a}{\frac{\pi}{n}}$ & 0 & 0 & 0 & 0 & 0 & 0 & 0 & 0 & 0 \\
\hline 0 & - & - & 0 & 0 & 0 & - & 은 & 0 & 0 & 0 & 0 & 0 & 0 & 0 & 0 & 0 \\
\hline- & 0 & 0 & - & - & - & 0 & 心 & 0 & 0 & 0 & 0 & 0 & 0 & 0 & 0 & 0 \\
\hline ర্ণ & ' & ' & ঠ্ণ & ষ্ণ & 유 & , & 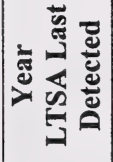 & ' & ' & ' & $i$ & ' & 1 & ' & ' & . \\
\hline ষ্ণ & ষ্ণ & ஓ्ন & 홍 & Б্ণ & Б্ & 휴 & 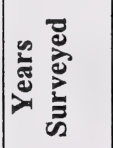 & 휴 & 휴 & 훙 & চ্ণ & ¿্ণ & ठ․․ & Б্ণ & 휴 & 휴 \\
\hline ' & ' & ' & ' & ' & ' & ' & 总 & ' & ' & ' & ' & ' & 1 & ' & ' & ' \\
\hline$\stackrel{\varrho}{ }$ & $\Xi$ & $\cong$ & $\cong$ & $\Xi$ & $\cong$ & $\varrho$ & \# & $\Xi$ & $\stackrel{\infty}{=}$ & $\stackrel{g}{ }$ & త్ & $\bar{\beth}$ & $\Xi$ & $\cong$ & $\stackrel{\Xi}{I}$ & $\cong$ \\
\hline
\end{tabular}




Bbliothèque nationale du Canada
Banala 